\title{
Sneaking Gender into the EFL Class
}

\author{
Antonio García Gómez \\ Departamento de Filologías Modernas \\ Universidad de Alcalá
}

Received: 31 May 2005 / Accepted version: 5 July 2005

ISSN: $1697-7467$

\begin{abstract}
The present study was conducted to engage undergraduate students training to be Primary School Teachers in the personal study of gender differences. More precisely the project aims, on the one hand, at getting undergraduates to openly explore the understanding of gender in the practice of teaching Primary school students and, on the other, at raising awareness of gender biased attitudes both in society and the classroom. My concern is that these future practitioners will be well positioned as teachers to reinscribe inequitable and discriminatory practices with their future students.
\end{abstract}

Key words: Gender Studies; Methodology; ICT in the EFL class.

RESUMEN: El presente estudio presenta un proyecto llevado a cabo con estudiantes universitarios de primer curso de Magisterio (especialidad de lengua extranjera) en la Universidad de Alcalá de Henares. Más concretamente, el proyecto fue conducido con el objetivo de involucrar a dichos estudiantes en el estudio de las diferencia de género, así como de hacerles conscientes de la importancia de adoptar una práctica docente que rechace la perpetuación de valores sexistas en el aula de primaria.

Palabras clave: Estudios de género; Metodología de la enseñanza del inglés; Uso de las nuevas tecnologías en el aula de inglés.

\section{INTRODUCTION}

It is essential to critically examine gender issues and, more specifically the stereotypes we learned as children, since they tend to shape us unconsciously as adults (cf. Nelson and Robinson, 1999). Although many people associate gender issues, sexist attitudes and prejudices with the stuff of ancient legends, this paper claims that gender stereotypes still play an important role in shaping people's lives. Far from being phantasms of marginal significance, there is compelling evidence to suggest that gender issues/stereotypes are vehicles for instilling cultural values and defining complex variables such as gender, power and notions of right (cf. Campbell et al., 1991).

Primary school teachers in particular and educators in general are in charge of one of the most difficult tasks in life: to fully educate children. Early in their lives, youngsters develop a gender identity, displaying behaviours that are more or less associated with males or females. These differences do not appear all at once, but rather become gradually more pronounced in each stage of development (cf. Grossman and Grossman, 1994). Whether gender variances are primarily biologically or environmentally determined is not the focus of this paper. Instead, by raising awareness of gender differences, practitioners can fully develop 
personal and social values in students. In other words, teachers play an important role in building up children's gender identity, and their knowledge of these differences will help them avoid repeating strong traditional male or female behavioural patterns.

The central issue at stake is a proposal to sneak gender into the ELF class. In particular, it argues the importance of sneaking gender into the EFL class and helping undergraduate students be aware of gender differences and inequities. In order to do so, Section 1 discusses the present situation of our education system. Section 2 deals with the method followed. Section 3 presents the methodology. Section 4 concentrates on the results of the project. Finally, section 5 is devoted to the conclusions.

\section{Present situation of the spanish education system: a Period of REFLECTION}

At present, our Spanish education system is calling for a period of reflection. It is looking for proposals, open to debate and self analysis that will lead to an improvement in the quality of the education system. The government has oulined its reasons for wanting to lift Spain's low standard of English proficiency. Such reasons have materialised in a working paper called Quality Education For All and Between All: Proposals For Debate. This paper has been inspired by the following basic principles: a) to provide a quality education for all; b) to firmly follow the educational objectives set out by the European Union; and c) to make a concerned effort to share education for all and between all.

In its fourth block, this working paper discusses the competences and knowledge needed in a $21^{\text {st }}$ century society. More precisely, the measures deal with a project that will broaden and improve efficiency in teaching and learning foreign languages and Information Communication Technology. Amongst the measures tied to foreign language learning and teaching, the most important are a commitment to early contact with foreign languages and the progressive opening of bilingual schools. This is due to the fact that Spain seems to be in a state of crisis, a simple inspection to undergraduate students in the English class reveals that the efforts put into language teaching lag far behind the results that should be achieved. Therefore, the opening of bilingual schools attempts to suit European aspirations of educating Primary students capable of speaking, apart from their mother tongue, at least one more community language. In its first block, however, the relationship between Quality and Equality is established. This block states that education should make an effort to compensate for lack of equality; thus, allowing all young people to enjoy the same opportunities and take advantage of the means that the education system puts within their reach.

An analysis of its seven blocks makes it possible to argue that there is an escalating awareness of promoting instructional, procedural, and behaviour management modification that allow for age, disability, and cultural differences. Yet when it comes to making allowances for gender, the cry is muffled. In fact, even though a number of approaches can be implemented to make school environments more palatable and productive for children, no suggestion has still been made.

The point of departure of this paper is the claim that while most teacher education programs provide training on diversity, learning disabilities, discipline, etc, they do not provide an instruction that addresses gender issues in the classroom. In other words, despite the fair 
amount of work examining the links between social problem solving and social maladjustment (Webster-Stratton and Lindsay, 1999), there remains a gap in the literature with regard to gender differences. Strong behavioural pattern can without any doubt dictate the type of relationship children have with their family, peers and teachers (Rinaldi and Howe, 1998). Yet few empirical studies have examined the construction of gender identities.

In what follows, I will present a project carried out with undergraduate students training to be Primary School Teachers at the University of Alcalá. The project is based on the idea that both undergraduate students and educators, in general, must engage in the personal study of gender differences in order to avoid passing on practices to teacher trainees that benefit one gender at the expense of the other. Thus, this video project aims at assisting students in becoming positive change agents.

\section{MethoD}

\subsection{Participants}

Participants were 69 male and 145 female undergraduate students training to be Primary School Teachers at the university of Alcalá de Henares. The proportion of female and male students is not even since most students in these classrooms are female. Participants range in age from 18 to 23 . To ensure that participants would be motivated to perform well, I assigned this task $20 \%$ out of the final mark.

\subsection{Procedure}

At the beginning of the course, students are asked to complete a questionnaire concerning their attitudes toward gender roles (See Appendix 1). The purpose is to get my students thinking and talking about attitude differences along gender lines as well as cross-culturally. As homework, students carry out their own writing assignment on gender differences: "Men are from Mars and Women from Venus". This writing assignment aims at getting students to think critically about how language reflects the world around them. The idea is not to deny that there may be an empirically observable association between a gender or style of speech and speakers of a particular gender. In practice this is undeniable (Cameron, 1998). What I intend to do is to make them understand that men and women are not reduced to automata, programmed by their early socialisation to repeat forever 'the appropriate gendered behaviour' (Cameron, 1998: 280); that is, women choosing cooperation and nurturing roles and men choosing antagonistic ones (cf. Holtgraves, 2002).

The second part of this measure requires participants to get involved in the creative task of scripting, producing and presenting a television advertisement in English on video targeting either male or female teenagers exclusively. It is important to have students reflect on ways in which gender has shaped their lives, both positively and negatively. Therefore, men need to think of ways in which gender has both privileged and disadvantaged them. For women, the converse may be true. Students are then encouraged to work together in same gender groups to select a product of their choice, real or imaginary.

There are a number of differences that may be found within advertisements aimed at 
different gendered audiences, including product association and gender portrayal. It could therefore be expected that product association will be different according to target audience, and incorporated into this will be alternative portrayals of gender. In addition to the tape recorders, students are asked to submit their taped comments along with a final draft in which they explain their advertisements and why they have made that choice.

\section{Methodology}

\subsection{Introduction}

At the university of Alcalá de Henares, first year students training to be Primary School Teachers are required to take a one-year EFL class called "English as a Foreign Language and its practical applications to the Primary classroom". Considering that the class only meets for three hours and a half each week, the project is mostly based on regular meetings outside the class. Once students have completed all the assigned tasks, the viewing and discussion of their advertisements take place in class.

\subsection{Why gender-differentiated advertisements?}

As Bailey (2004) points out, advertisements appear to be everywhere in contemporary society. For instance, Williamson (1978: 17) claims that advertisements permeate society, influencing everyone's lives, and that they are not "simply a transparent vehicle for a "message" behind it'. In a nutshell, scholars agree that advertisements tell us who we are and who we should be (cf. Kilborne, 1995).

A basic fact about advertisements is that they are not aimed at everybody; instead they have specific target audiences (age, social and economic status, or gender). A broad literature on the topic has argued that people filter their impressions to retrieve the messages relevant to them (cf. Vestergaard and Schroder, 1985). For instance, in an analysis of over 2,000 television advertisements, Craig (1992) concluded that advertisers 'structure the gender images in their commercials to match the expectations and fantasies of their intended audience' (Craig, 1992). This may be viewed as pleasure gained through a process of identification, with advertising functioning 'as an ideological apparatus for the reproduction of our gender identities' (Vestergaard and Schroder 1985: 73-74). It could therefore be expected that product association will be different according to target audience, and incorporated into this will be alternative portrayals of gender (cf. Phakiti, 2003).

In the light of this, I decided to ask students to script their own gender-differentiated advertisements. The key issue here is that these video recordings are the ideal data to analyse the construction of adolescent social and gender identities and raise awareness of those gender issues ${ }^{1}$ students should know as future practitioners. More precisely, the analysis of

1 The term 'gender issues' refers 'to the social and educational aspects of the pupils' being male or female; that is to say, to the real and perceived biological, genetic, cultural, educational, and indeed lifelong implications of the gender (Portwood, 2000: 34). 
these videotapes could shed new light on the processes of self-identification and categorisation in L2 interactions.

\subsection{The project}

As mentioned before, the project is divided into different scheduled phases that vary in length according to the amount of work students have to prepare for the next deadline. It is necessary to highlight that some of the phases proposed are not entirely original but have been adapted from Liu's (1997) proposal to use the camcorder in the EFL classroom. However, the idea of combining the video camera project with gender issues responds to my personal preoccupation with sneaking gender into the English class. In what follows, I will describe its different phases:

Phase 1. Project presentation (timing: one week). After having carried out this proyect for the last four years, I know that the video camera project requires a lot of time and energy from students. Therefore, I inform students at the beginning of the term that they must carry out a video project. In addition, I always state the schedule clearly on the syllabus so that students will have plenty of time to prepare for it. Unfortunately, learning is not always appealing to students; that is why, I present the project as a 'lifeline' useful for improving students' marks. Once students realise that it counts, they are willing to spend more time on this activity. It is worth saying that after some weeks working on the project the mark on the project becomes secondary and pleasure for its own sake leads the way. Moreover, I assure my students that I will guide them through every step. As long as they follow the schedule on the syllabus, they can definitely finish the task without the pressure of time.

Phase 2. Do's and Dont's (timing: one week). After the success of the first video camera project experience, the following academic years I have shown some of the video tapes produced by former students. This really gives a clear picture about what I expect them to do. By showing one or two of the best videos to students, I can give students something to aim for. In other words, this is a simple way to show students that if former students could do it, they can also do it. Even though I always give precise instructions about the type of setting they must choose (right location, enough light, loudly enough), I find it interesting to view some video tapes that are functionally improper. For example, too much noise, not enough volume, a blinking low battery signal in the upper right corner, etc. The idea is to prevent students from making the same mistakes. Even though students do not have professional video taping skills, there are some basic requirements they must bear in mind if they want the audience to understand what is going on (cf. Stokes, 2001).

Phase 3. Brainstorming and Group formation (timing: one week). Then I divide students into small groups of four to six people. Students are free to choose their own workmates. However, I recommend them to work together in same-gender groups. Allowing students the freedom to choose who they would like to work with definitely improves their cooperation and thus the outcome of the performance. Once students have got into groups, I ask them to work out ideas for the video advertisement. Although I always give them some ideas to start with, the reality is that students end up choosing some other items that I could 
never have imagined. Every year they surprise me with their creativity. I strongly agree with Celce-Murcia and Hilles (1988) on their claim that the more freedom students are given, the more creative they tend to be.

Phase 4. Data collection and Script editing (timing: two weeks). Once the group has decided the items they want to advertise, the different groups have to do some research about male and female preferences. I ask them to talk to their friends, some other classmates to collect information about the things they would like their product to have. After carrying out their research, they are ready to work on the actual scripts. Each group has to write two dialogues, one for each ad. When they have prepared the dialogues students hand in the script, and the next step is for me to edit students' work so that the language is grammatically correct and idiomatic. In fact, I usually assess their command of English and plan my following sessions to work on the recurrent structural errors they have. The aim of correcting their scripts is not only to assess, but also to provide some feedback. For this purpose, I meet each group and we discuss what they wanted to say so that I can brush up their scripts without losing their spontaneity.

Phase 5. Lights, Camera, Action! (timing: three weeks). After having discussed with students the aim of their advertisements and having corrected their scripts, students have to type it up and make enough copies for each member of the group. Then, it is time for individual students to work on their own lines. I always advise students to act out their role in a natural way. They are always welcome if they want to rehearse with me, we can then work on pronunciation, intonation, movements, gestures and facial expressions. At the end of the day, their own personalities and acting styles are much more effective than any piece of advice they may be given.

The rehearsal is the prerequisite for the videotape performance. Students are asked to rehearse their ad numerous times. Above all, students will be reminded to speak as clearly as possible so that their performance can be understood. More than one appointment is generally used. Then, students are ready to videotape their performance. It is worth saying that the video camera is user-friendly, students seldom have problems operating it by themselves. They have been born in the new tech era.

\section{Phase 6. Handing over the project (timing: one week).}

The advertisement is due in week 10, together with the script. After watching all the advertisements, I arrange the video presentations to be viewed in two to three weeks. On the one hand, it is show time, the moment the whole class has been waiting for. Students do enjoy seeing themselves and their classmates on television. On the other hand and after enjoying the fun of the video presentations, students discuss their opinions about gender issues.

\section{Results of The Project}

Teaching gender is not always pleasurable. Gender is pervasive throughout our experiences and, as such, can be an emotionally volatile topic to deal with in a classroom. In what follows and contrary to previous studies that have primarily focussed their attention on word and sentence level choices (cf. Holmes, 1995; Blackburn-Brockman, 2001), my analysis will explore gender at discourse level. The aim is to show that there is indeed a dialectic relationship 
between the selection of specific roles for Self-and-Other gender presentation in students' scripts and their underlying biased attitudes. In other words, I will attempt to shed further light not only on how gender influences students' script editing, but also how gender intersects with personality features and the construction of the adolescent Self.

In this light, it is worth pointing out that my approach to gender identity construction is therefore broadly influenced by Social Constructionism, and in particular by the notion of the Self as a social and a discursive project (cf. Potter and Wetherell, 2003). In general terms, to say that a person has a Self is to say, in the first place, that he or she is capable of engaging in self-reflection or what has been called self-reflexivity. In line with Giddens (1991), I suggest that the study of gender identity needs to be undertaken bearing in mind that the male or female Self is not a fixed, complete entity but an ongoing project. In addition, this paper makes the argument that the reflexive project of the Self in all the scripts operates within a constant struggle against commodified influences. This is demonstrated through the analysis of all the scripts students have edited which establishes a clear distinction between Selfpresentation strategies and Other-presentation strategies.

As far as the Self-presentation strategies are concerned, the analysis reveals that both genders portray an unrealistic positive view of their own gender; that is, male and female students always use self-enhancing illusions when depicting their Self and, in turn, their own gender. These unrealistic views are mostly about exaggerating their own talents, abilities, and social skills. In the analysis of male and female depictions of their own gender, it can be then claimed that self-presentation becomes a mediated process and the project of the Self becomes translated into one of the 'possession of desired goods and the pursuit of artificially framed styles of life' (Giddens, 1991: 198). The following tables compile the most common depictions found in male and female's advertisements:

\section{Table 1. Men depicting men}

- Men socialise by swearing and showing off their physical strength.

- Men's worries centre on their physical strength.

- Men speak openly about any topic: sex, religion, etc.

- Men enjoy discussing about serious matters concerning the world.

- Men are not worried about their physical appearance.

- Men live to satisfy their needs.

\section{Table 2. Women depicting women}

- Women are understanding and sympathetic.

- Women express their emotions openly.

- Women share information to build interpersonal relationships.

- Women adopt nurturing roles and are more responsible when facing obligations.

- Women are always worried about their physical appearance, what to wear, etc.

- Women are more sincere than men are. They are driven by their true feelings.

- Women are very critical about what they say, and what they do. 
On the surface, these two tables appear to be a mere compilation of common stereotypical gender notions: the male Self is depicted as a competitive, argumentative and more verbally aggressive gender whereas the female Self is understood as more cooperative and personoriented (cf. Coates, 1996). However, a detailed analysis makes it possible to argue that students' Self-presentation of their own gender shapes male and female Selves as different social subjects or social products (cf. Fairclough, 1989).

To say that students' Self-presentation is a social product entails two premises. First, that the sense of Self and the resulting gender identity arises from publicly validated performances. Second, that although individuals play an active role in moulding these self-indexing performances, they are generally constrained by the need to project self-images that are socially supported within the context of a given status hierarchy (Goffman, 1974). Identity and gender constructions, then, are not crafted in a social vacuum but within specific social settings that take the identities of others into consideration. The notion of the Self as a social product is, thus, intertwined with that of social accountability. In a way, this claim extends the traditional feminist accounts whereby gender is socially constructed rather than natural.

With regard to the Other-presentation strategies used in students' advertisements, the analysis supports my line of argument. The downward social gender comparison on which both male and female depictions are based, suggests that the perception of Self and gender identity is based upon the social constructionist belief that identity is constituted and ratified in discourse. Therefore, the fact of using downward social gender comparisons creates a 'frame' (cf. Goffman, 1974) for personal experiences that holds implications for the other gender identity and their own. Before drawing further conclusions, consider the most significant depictions chosen for the other genders:

Table 3. Men depicting women

- Women keep up phoney relationships. They enjoy speaking ill of others.

- Women avoid speaking about certain topics (e.g. sex).

- Women only enjoy speaking about unimportant matters (clothes, make up, etc) and spend most of the day in front of the mirror.

- Women in love live to satisfy their boyfriends' needs.

- Women are always over-emotional.

- Women are represented as dependent on men's protection.

- Women are regarded as sex objects or as domestic adjuncts.

Table 4. Women depicting men

- Men are unable to understand women's feelings, ideas, and interests.

- Men avoid expressing their feelings.

- Men enjoy giving information as a way to show expertise.

- Men are self-centred and have a different sense of priorities.

- Men appear to ignore their physical appearance.

- Men lack sincerity and are able to hurt people to achieve their goals.

- Men are driven by their hormones.

- Men lack a critical eye with respect to the way they are and the way they behave. 
Other-presentation strategies reveal that gender identity is best characterised as multifaceted and strategic insofar as individuals construct their gender identities to make them as appealing as possible to others. In other words, both male and female students' negative depiction of the other gender try to control how the other gender must be perceived by others. Furthermore, both genders choose those characteristics that are as opposed as possible with the demands of the social order.

Finally, this divergent presentation of the other gender, on the one hand, suggests that the negative depiction provides individuals with a way to organise their sense of selves. That is to say, this presentation appears to be a gender-based distancing strategy or a tactic of male or female (inter-group) distinctiveness employed by one gender or the other in search of positive identity. As Giles and Coupland (1991) notes, these opposing depictions tend to be caused by the desire for social integration on the part of same gendered groups.

\subsection{Conducting investigative research with undergraduates to understand gender}

What good will come out of a heightened awareness of gender in their future teaching practice? How will gender awareness benefit them as individuals and future practitioners? Even though it is not possible to measure students' change in students' attitude towards a biased gender attitude, I can only plant the seeds that some day will blossom. These metaphorical seeds are the investigative research I conduct with students at the end of the project to understand gender and identify gender biased attitude both in the classroom and society. This research is divided into two main parts: student voices and teaching for change.

As for the first part, my aim is to let students have their say about the role of gender in their advertisements. By means of in-class discussion, students brainstorm the traditional stereotypes that are present in their scripts. For this purpose, I give students some strips of paper with general questions on what they have just watched. The following sentences are examples:

- What roles are most often assigned to women/men in the advertisements?

- What attributes or associations are tied to certain behaviours and certain types of women/men? (i.e. women always interested in being beautiful to get married or men always boasting about their physical strength?)

- How and why do female/male characters succeed or fail in selling their products?

- How are "femininity" and "masculinity" defined? What is a "woman"? What is a "man" in the advertisements?

- What are the qualities of a "good" or "bad" woman or man?

- Do the advertisements reinforce or challenge patriarchy?

The main objective of this discussion held in class is to make them see the importance of gender inequities while they practise their speaking skills. In line with previous studies of this nature (cf. Flynn, 1990), students' proposals respond to their gender. On the one hand, male students say to get their sense of self from achievement and being self-reliant is very important to them. Female students, in contrast, get their sense of self from relationships and tend to be relational-oriented. In addition, male students usually focus on a goal whereas female ones enjoy the process. In a nutshell, men are competitive, they are driven to prove 
themselves, to prove that they are competent, and it comes out in a competitive spirit. Still, women are more cooperative than competitive

The second part of the research responds to a significant gap in pedagogy: the examination of gender in learning environments and classroom interactions. Teaching for change provides evidence in support of two main key issues: the need to gain awareness of the importance of creating learning environments that help both male and female students acknowledge and overcome obstacles to equitable gender relations; and the need to sneak gender into the EFL class in order to analyse the effect of gender stereotypes on children's psychological wellbeing.

Taking the constant presence of gender stereotypes in EFL printed materials as the point of departure, I encourage students to embark on the adventure of designing materials and tasks that do not contribute to these stereotypes. There is no doubt that Primary school students start discovering and inspecting the world around them in our classroom. In this way, the investigative research consists in designing both materials and tasks that avoid selfstereotyping, school stereotyping, and family/cultural stereotyping by gender. Most of the materials that have been designed so far are a set of supplementary tasks to illustrate different aspects of the foreign language curriculum (i.e. the family, parts of the body, free time activities, etc.).

Positive effects of this investigative reach are already been seeing, undergraduate students have started integrating gender content into their own teaching practices. One of the most successful tasks designed in class with them has been 'life swap'; that is, to learn by being in somebody else's shoes. There is no doubt that its effectiveness stems from Primary school students relying on what they directly experience, do or perform. In terms of the main curricular contents, undergraduates designed different role-plays where students swap their lives with their mums if they are boys and their dads if they are girls. For example, when working on family and family values, school boys, on the one hand, are encouraged to carry out a mini-project on their mums' household duties. Apart from reporting what they see at home, they have to act out different role-plays pretending they are their mums. Not only do they learn to appreciate household chores and be a twenty first century husband but they also overcome their reluctance to pretend they are women. On the other hand, school girls carry out the same project. In class, they are involved in group tasks where they are encouraged to make decisions and also in information-gap and role-play activities so that they can learn and become aware of women's diverse roles in society. All in all, this type of tasks enhance Primary school students' learning process, motivate them and can also be understood as one step toward gender equity.

\section{Conclusion}

Promoting issues such as gender equity is a pending subject in our education system. Apart from the initiative of a few enthusiastic faculty members, there is still much to be done. This work includes qualified educators, textbooks, and methodological materials on gender. The workshops held so far focussed on gender socialisation and stereotypes, trafficking, gender aspects in politics and education acknowledge the importance of introducing gender studies in their curricula. 
All in all, this research with students demonstrates how they can benefit from engaging such themes in the classroom as opposed to being subjected to a steadfast avoidance of them. In addition, information stemming from this type of research can also be useful in designing prevention and intervention programs and for redesigning traditional social skills programs. Certainly, non-discrimination guarantees must be developed and enforced, but re-engineering the classroom to create a "gender-free" environment is a "politically correct" response that is educationally unsound. Gender based differences must be recognised, respected, and addressed.

\section{REFERENCES}

Alessi, S.M. \& Trollip, S.R. (2001). Multimedia for Learning: Methods and Development. Third Edition. Allyn \& Bacon, A Pearson Education Company.

Bailey, R. (2004). "Gender-Differentiated Car Commercials". Available http: http://www.aber.ac.uk/ ednwww/Undgrad/ED30520/hingham2.html

Bello, T. (1999). "New avenues to choosing and using videos", in TESOL Matters, 9 (4), 20.

Blackburn-Brockman, E. (2001). "Investigating the Role Gender Plays in Adolescents' Writing Processes and Products". Available http: http://scholar.lib.vt.edu/ejournals/WILLA/fall01/ blackburn.html

Campbell, J., Moyers, B. and Flowers, B.S. (1991). The Power of Myth. New York: Anchor Press.

Cameron, D. (1998). "Performing Gender Identity: Young Men's Talk and the Construction of Heterosexual Masculinity". In Coates, J. (ed.), Language and Gender. A Reader. Blackwell Publishers.

Celce-Murcia, M. and Hilles, S. (1988). Techniques and Resources in Teaching Grammar. Oxford: Oxford University Press.

Coates, D. (1996) Women Talk: Conversation between women friends. Oxford: Blackwell.

Colmes, J. (1995). Women, Men and Politeness. London and New York: Longman.

Craig, R. S. (1992). "The Effect of Television Day Part on Gender Portrayals in Television Commercials: A Content Analysis", in Sex Roles 26(5/6): 197-211.

Davis, R.S. (1999, June/July). "Video in the corridors of cyberspace", in TESOL Matters, 9 (3), 14-15. (http://esl-lab.com/tutorials/lesson4.htm).

Fairclough, N. (1989/94). Language and Power. London: Longman.

Flynn, B.L. (1990). «Images: Women and Issues». In Sightlines. v. 25: 14-16.

Giddens, A. (1991). Modernity and Self-Identity. Cambridge: Polity Press (in association with Blackwell).

Giles, H. and Coupland, N. (1991). Language: Contexts and Consequences. Buckingham: Open University Press.

Goffman, E. (1974). Frame Analysis, NY: Harper Colophon.

Grandjean-Levy, A. (2002). Caught in the Net: Technology and Teaching Languages Courses. Ohio: Prentice Hall.

Grossman, H. \& Grossman, S.H. (1994). Gender issues in education. Boston: Allyn \& Bacon.

Holmes, J. (1995). Women, Men and Politeness. London: Longman.

Holtgraves, T. M. (2002). Language as Social Action: Social Psychology and Language Use. Mahwah, New Jersey: Lawrence Erlbaum Associates, Publishers.

Johnston, J. (1999). "Enhancing adult literary instruction with video" Unpublished manuscript, University of Michigan-Ann Arbor.

Kilborne, J. (1995). "Beauty and the beast of advertising", in G. Dines. \& J. Humex (Eds.), Gender, race and class in media. (pp. 121-125). Thousand Oaks: Sage Publications. 
Ktoridou et al., (2003). "Integrating Technology in EFL” Available http: http://www.uncw.edu/cte/ etartciles/Ktoridou2/

Liu, Y-H. (1997). "Video presentation: Using the Camcorder to work miracles in the EFL classroom", in ThaiTESOL Bulletin, Vol.10, No. 2, August, 1997.

Morris, K.A. (2000). Don't overlook the teacher educator: A study of video guidebooks as opportunities for teacher educator learning. Research Report to the MacArthur Foundation.

Nelson, E. D. and Robinson, B. W. (1999). Gender in Canada. Scarborough: Prentice Hall Allyn and Bacon Canada.

Phakiti, A. (2003). A Closer Look at Gender and Strategy Use in L2 Reading", in Language Learning. 53(4). 649-702.

Potter, J. y Wetherell, M. (2003). "Rethinking cognition: On Coulter, discourse and mind". Human Studies 26: 165-181.

Portwood, M. (2000). Understanding Developmental Dyspraxis. London: David Fulton

Rinaldi, C. and Howe, N. (1998). "Siblings' reports of conflict and the quality of their relationships", in Merrill-Palmer Quaterly, 44, 404-422.

Stempleski, S. (1992). "Teaching communication skills with authentic video" in S. Stempleski \& P. Arcario (eds.), Teachers of English to Speakers of Other Languages, Inc. (EDRS No. ED 388 082).

Stokes, A. (2001). "The one-computer classroom", in English Teaching Professional, January, 2001 issue 18, Cambridge: UK.

Vestergaard, T. \& Schroder, K. (1985). The language of advertising. Oxford: Blackwell.

Webster-Stratton, C. \& Lindsay, D. W. (1999). "Social competence and conduct problems in young children: issues in assessment", in Journal of Clinical Child Psychology, 28 (1) 25-43

Williamson, J (1978). Decoding Advertisements. London: Marion Boyars.

Yao, C. (1994). "A Study of College EFL Lab Listening Class: The Chung Hsin University Experience". Paper presented at the National Science Council of the Republic of China. 


\section{APPENDIX 1 \\ Gender Questionnaire Data Analysis. Sample}

Gender : Male Female

Age :

0. Men and women behave differently. Describe those behaviours you relate to each of them. Give examples:
a) Characteristic behaviour of men:
b) Characteristic behaviour of women:
c) Characteristic behaviour shared by both men and women:

1. In your opinion, what is the characteristic behaviour of a man or a woman in the following settings. Give examples:
a) At home
b) At university
c) In a bar
d) In a disco
e) In a conversation with his/her best friend

2. As a man or a woman:

a) Which behaviour would you NEVER adopt in public because you think it is not prototypical of your gender?

b) Which topics would you NEVER introduce or talk about because they are not appropriate for your gender?

c) How would you judge those who do and say what you think is not appropriate for their gender? 